\title{
The church as a transformation and change agent
}

\begin{tabular}{|c|c|}
\hline \multicolumn{2}{|l|}{$\begin{array}{l}\text { Author: } \\
\text { Jerry Pillay }{ }^{1} \text { (D) }\end{array}$} \\
\hline \multicolumn{2}{|c|}{$\begin{array}{l}{ }^{1} \text { Department of Church } \\
\text { History and Church Polity, } \\
\text { Faculty of Theology, } \\
\text { University of Pretoria, } \\
\text { South Africa }\end{array}$} \\
\hline \multicolumn{2}{|c|}{$\begin{array}{l}\text { Research Project } \\
\text { Registration: } \\
\text { Project Leader: J. Pillay } \\
\text { Project Number: } 04653484\end{array}$} \\
\hline \multicolumn{2}{|c|}{$\begin{array}{l}\text { This research is part of the } \\
\text { project, 'African Christianity } \\
\text { and Development', directed } \\
\text { by Prof. Dr Jerry Pillay, } \\
\text { Department of Church } \\
\text { History and Church Polity, } \\
\text { Faculty of Theology, } \\
\text { University of Pretoria, } \\
\text { South Africa }\end{array}$} \\
\hline \multicolumn{2}{|c|}{$\begin{array}{l}\text { Corresponding author: } \\
\text { Jerry Pillay, } \\
\text { jerry.pillay@up.ac.za }\end{array}$} \\
\hline $\begin{array}{l}\text { Dates: } \\
\text { Received: } 22 \text { S } \\
\text { Accepted: } 07 \text { I } \\
\text { Published: } 22\end{array}$ & $\begin{array}{l}\text { ept. } 2016 \\
\text { Mar. } 2017 \\
\text { May } 2017\end{array}$ \\
\hline \multicolumn{2}{|c|}{$\begin{array}{l}\text { How to cite this article: } \\
\text { Pillay, J., 2017, 'The church as } \\
\text { a transformation and change } \\
\text { agent', HTS Teologiese } \\
\text { Studies/Theological Studies } \\
73(3), 4352 \text {. https://doi. } \\
\text { org/10.4102/hts.v73i3.4352 }\end{array}$} \\
\hline \multicolumn{2}{|c|}{$\begin{array}{l}\text { Licensee: AOSIS. This work } \\
\text { is licensed under the } \\
\text { Creative Commons } \\
\text { Attribution License. }\end{array}$} \\
\hline \multicolumn{2}{|l|}{ Read online: } \\
\hline 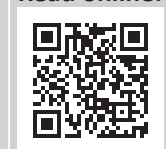 & $\begin{array}{l}\text { Scan this QR } \\
\text { code with your } \\
\text { smart phone or } \\
\text { mobile device } \\
\text { to read online. }\end{array}$ \\
\hline
\end{tabular}

This article traces the historical impact of the church in transforming, developing and changing society. It looks at how the church in selected periods in history, mainly in the reformation era, worked towards the transformation of society and communities. Extracting from these the author attempts to show how this can be applied to the church in the South African context. Further, the author explores the changing dynamics and characteristics of being church today and establishes that it is not so much about what the church believes, but in what it does that matters most in this day and age. The author, with the latter thought in mind, expresses that community transformation has to be an integral part of the ministry of the church today.

\section{Introduction}

Today much emphasis is placed on the role of the church as a transformation and change agent and rightly so (see Bosch 1999:376-393). However, this is not a new concept or understanding of the role of the church. Throughout the ages, as I will show, in spite of other ecclesiologies the church has been involved in the life of humankind, in making of nationhood, building of culture, structuring of society with its functions and institutions and in shaping the form and quality of political systems.

The Church of Jesus Christ has normally understood the transformation of society to be an essential part of its mission task. ${ }^{1}$ While the focal point of missions has been to communicate the Good News of Christ, to call men and women to repentance and faith, and to baptise them into the church, it has also involved a process of teaching them to 'observe all things' that Jesus commanded. Christians have assumed that this obedience would lead to the transformation of their physical, social and spiritual lives. Sometimes this has been well done, sometimes poorly done. But missionaries have always implicitly assumed that the reception and the living out of the gospel would begin to transform both individual and community life. ${ }^{2}$ And more often than not, specific steps were taken and institutions were established to aid this process. While we recognise today that the missionaries often envisioned a model of the transformed community that looked suspiciously like the ones they knew in their own cultures, there is no doubt that this transforming dimension was an essential aspect of mission.

We shall now attempt to see how the Christian church right from its inception was involved in the transformation of society. Our attempt is not to provide a history of Christian mission per se but to show that the church has always had a concept of transformation and change in its mission and ministry, especially as it relates to the poor. There is a deeper resurgence of this quest for the role of the church in bringing about transformation and change in the world by focusing on the mission of the church. Missional seems to be the buzz word today. Reggie McNeal states that the rise of the missional church is the single biggest development in Christianity since the Reformation (2009:xiii). He points out that this is not doing churchas-usual. Going missional requires three shifts: (1) from internal to external in terms of ministry focus, (2) from programme development to people development in terms of core activity and (3) from church-based to kingdom-based in terms of leadership agenda (McNeal 2009:xiv). Speaking about the missional renaissance, McNeal asserts that this is changing the way the people of God think about God and the world, about what God is up to in the world and what part the people of God plays in it.

1.To transform, dictionaries say, is 'to change in character or condition to alter in function or nature'. The noun transformation then refers to the action of bringing about such a change. The Greek-derived synonym of this Latin-based word is metamorphosis.

2.Furthermore, Christian missions have also been a result of renewal movements in the church, for example, Pietism. Such movements, more often than not, attempted to transform their own societies, or at least to focus on both evangelisation and service to the poor, the marginalised and the oppressed. Thus, it is natural that the missions coming out of such movements took the same concerns for the poor and oppressed to their fields of labour. 
While the major focus of this study is on the Reformation period it is important to go before then to briefly look at how the early church and medieval period also looked at the transformation of society and community. This helps us to gain a fuller picture of the church as a change agent. McGrath points out that in recent scholarship there is a tendency to place the Reformation movement in its late medieval context to bring together the insights of the late medieval, Renaissance and Reformation studies (2012:23). He points out that synthesis and consolidation are essential to the correct understanding of the ideas of the Reformation. Thus it is for this reason that we would begin by examining the role of the church in transforming society in the early church and medieval period.

\section{The early church}

Jesus and the apostles functioned within the society in which they were found. Hence, the socioeconomic and political factors of the day were to greatly influence the teachings of Jesus and his disciples. In taking sides with the poor, Jesus attacked the Pharisees and Sadducees for their selfindulgence and greed (Matt 23:25-33). They were known for their oppression and exploitation of the poor peasants. Society was conditioned by social and group distinctions and it relied on a slave economy (Batey 1972:5). Jesus' preaching about the 'Kingdom' made it abundantly clear that God took seriously the concerns of the poor and needy: the poor would be blessed in the realisation that the 'Kingdom of God' was theirs (Lk 6:20-26); even tax collectors and harlots would gain entry before those who appeared to be religious and respectable (Matt 21:31-32), and the rich and saturated would become acquainted with want and hunger. The arrival of the 'Kingdom' contained the seeds of economic revolution and social reversal. With all these we, however, do not find a 'pattern' of a fully orbed programme to transform society in the life of the early church. This, however, radically changed when the church moved out beyond the borders of the Graeco-Roman frontiers.

Bruce Winter in his careful and well-documented discussion of public life in the 1st century shows how early Christians took part in public life in the Greco-Roman communities in which they lived (Winter 1994:200f.). He argues that 'the early church in fact taught a civic consciousness among its members'. Christians were not to abandon life in public sphere (politeia) but to address their obligations as citizens from the perspective of the Christian ethic.

Winter holds that the Christian community, while maintaining a commitment to the tradition of benefaction of the classical city, required all its citizens, whatever their financial resources, to contribute to the welfare of the city even in the face of persecution. They thus saw themselves as practising a new and strange politeia. Winter concludes that the Christian social ethic ... was an unprecedented social revolution of the ancient benefaction tradition. Every Christian had an obligation to promote the welfare of the city and help the poor, even without the rewards that were traditionally accorded the benefactor.
David Bosch points out that transformation (humanisation) has been a part of the Christian mission and influence in society right from the beginning (Bosch 1999:180). In a society described as 'macabre, lost in despair, perversion, and superstition', Christian communities emerged as something entirely new in the populous and far-flung Roman Empire. The early church was on the periphery of society. It found many of its earliest adherents among slaves, women and foreigners - people who had no special influence on the shape of society. Yet it was to have an impact on society, especially over the next two millennia.

Christianity began by preaching and practising the 'gospel of love and charity' which included almsgiving and care for widows, orphans, slaves, travellers, the sick, the imprisoned and the poor (Von Harnack 1967:147-198). Driven by the love of Jesus believers went out and expressed their love for the neighbour. The early disciples showed true mercy and compassion. Peter, who had no silver or gold on his person, gave a crippled beggar what he did have: the gift of health (Ac 3:6). Tabitha (Dorcas) is cited as an early disciple 'full of good works and acts of charity' (Ac 9:36).

Generally speaking, the New Testament sees the ministry of mercy not only as an individual obligation, but also as a corporate endeavour of the church, to be carried out by the church itself. 'So then, as we have opportunity, let us do good to all men, and especially to those who are of the household of faith' (Gal 6:10). Thus members of the first Christian congregation 'sold their possessions and goods and distributed them to all, as any had need' (Ac 2:45). The early Christians in Jerusalem were organised on determinedly egalitarian lines, practising community ownership of property. Women played as prominent a role as men did. Slaves and freed men and women shared equally with the freeborn (Stanmaugh \& Balch 1986:55). Within the group, at least in the early decades, there was a conscious rejection of the status-conscious norms of society, a rejection summarised in the admonition that within the community of the baptised there was 'neither Jew nor Greek ... slave nor free ... male nor female' (Gal 3:28; cf. Jas 2:2-12).

As the church spread through the Roman Empire its ministries of mercy underwent considerable development. Social relief became a monopoly of the church in Rome and Alexandria, where it was manifested in distributions to the poor and in the establishment and upkeep of hospitals, orphanages and homes for the aged. By the 4th century the church was also bringing relief to people whom inflation had plunged into distress.

During the time of Constantine the church enjoyed much favour. Constantine's attempt to create a Christian empire eventually resulted in the state taking over much of the responsibility of the church. For example, the state now assumed as its responsibility the care of the poor though the church continued with this on a small scale. To Constantine himself is credited the observation that a changed religion 
involves a changed social order. As a matter of fact the Constantinian policy embraced two parallel but distinct objects. These objects may be described as follows (Cochrane 1974:191-211): (1) to create a world fit for Christians to live in and (2) to make the world safe for Christianity. The former represents the attitude of the emperor to individual believers; it finds expression in an extensive scheme of moral and social reform designed to satisfy their demands and to promote their interests. The latter reflects his views regarding the Church as an institution, and it manifests itself in the project of a Christian establishment conceived more or less along the lines of existing pagan state-cults.

Constantine's reforms were limited to a certain tenderness towards dependents, women, children and slaves. Women, for example, were no longer to be compelled to undergo trial in the public courts, widows and orphans were to have special consideration at the hands of the judiciary and they were not to be forced to travel long distances for hearings (Cochrane 1974:191-211). A law that forbade the separation mitigated the hardships of slavery by sale of man and wife, and the practice of manumission was encouraged, especially if it took place in the church. In other respects, also, the emperor tried to maintain the cohesion of the family, especially by prohibiting divorce except on statutory grounds: to the specific exclusion of 'frivolous pretexts' such as drunkenness, gambling and infidelity.

Constantine also called for the prohibition of gladiatorial exhibitions and the abolition of crucifixion as a form of punishment, no doubt out of respect for the memory of Christ. With this tasteless expression of Christian sentiment may be compared the enactment which forbade the branding of human beings on the face 'because the face is made in the image of God', while slaves, criminals and even conscripts continued to be branded on other parts of the body (Cochrane 1974:191-211).

In the earliest stage of his public career, Constantine maintained a more flexible though still strictly aristocratic type of society. Once in power, however, he seems to have abandoned any such notion; for he maintained in all its rigour, the legal framework of the status-society. He promoted the tendency towards social evolution upon an occupational basis; in each and every case seeking to attach to the legal person fixed obligations commensurate with the privileges to which his status in the community entitled him; and, at the same time, scattering immunities and exemptions with a generous hand among favoured groups whose services he regarded as peculiarly valuable to the regime. This programme was said to demoralise the middle groups while, at the same time, it transformed the free peasant into a serf. Yet as a jurist declared, 'though Christianity came to proclaim the gospel to the masses, it arrived too late to effect any decisive reform in existing economic conditions' (Stanmaugh \& Balch 1986:204).

Post-Constantine churches spent great sums on the work of ransoming captives. St Ambrose proposed selling the precious vessels on the altars of his church in Milan to do just that. He declared:

There is one incentive which must impel us all to charity; it is pity for the misery of our neighbors and the desire to alleviate it, with all the means that lie in our power, and more besides. (Scott 1987:208)

As we have shown, there is no doubt that the early Christian centuries were a period of significant social change and restructuring, witnessing the spread of Roman power across the Greek East as well as the emergence of Christianity and rabbinic Judaism. The emergence of a new cultural form both indicated and enabled broader societal transformations (Perkins 2005:46). In spite of what we have just noted, however, it can hardly be maintained that the early Christians deliberately attempted to restructure the empire in addressing matters of socio-economic justice. Instead, during the first two centuries when Christians constituted a small minority, their concern was to help those who were dehumanised and oppressed by providing practical help. Their concerns were motivated by compassion and characterised by communal justice and the love of God. Their input into changing society was essentially to provide charity and love as expressed in the Scriptures. Yet they were to have a profound effect in helping the poor and neglected.

\section{The medieval church}

The medieval period was built on a system of feudal hierarchy. In this hierarchy, the lord of the manor, who, in turn, owed allegiance to and was protected by a higher overlord, protected the serf, or peasant. And so the system went, ending eventually with the king. This hierarchical and systemic differentiation was generally biologically based, with birth right crucial to one's place in feudal society, as was hereditary provenance. Those who worked were usually assigned to the lowest classes; those who escaped the burdens of ordinary labour were of higher class standing (Hunt \& Sherman 1981:4). Such a structure led to the exploitation and oppression of those lower in the hierarchy.

The Catholic Church was by far the largest owner of land during the Middle Ages. The bishops and abbots, in exercising a primary loyalty to the church in Rome, provided a strong central government throughout this period. Hence the manor functioned on both a religious and secular basis. The dominant economic institutions in the towns were the guilds who were also involved with social and religious questions. They regulated their members' conduct in all their activities: personal, social, religious and economic. Although the guilds regulated very carefully the production and sale of commodities, they were less concerned with making profits than with saving their members' souls. Salvation demanded that the individual lead an orderly life based on church teachings and custom.

The church advocated a moral code sometimes called the Christian corporate ethic, reflecting the fact that all of society was considered a single entity or corporation (Hunt \& 
Sherman 1981:6). This led to a strong paternalistic obligation towards the common people, the poor and the general welfare of society. It was accepted that some were to be rich, and that the poor had to subordinate to the leadership of the wealthy. However, it was equally emphasised that the wealthy had an obligation to use their riches to help the poor. Hence riches and wealth were not condemned, but greed, selfish acquisitiveness, covetousness and the lust for wealth were consistently condemned by the Christian paternalist ethic. What we do see here is a concern for the poor. However, the support of wealth (and not greed or selfish acquisitiveness) was to obscure the absolute biblical focus on the poor that Jesus advocated.

The teachings of Christ in the New Testament carry on part of the Mosaic tradition relevant to economic ideology. He taught the necessity of being concerned with the welfare of one's brother, the importance of charity and almsgiving. He condemned the rich and praised the poor as he took their side. The medieval church in many ways attempted to remain true to the teachings of its Lord as it set out to develop its society politically, economically, socially and religiously. However, while on the one hand the Church drew up guidelines for helping the poor, and their assistance was structured accordingly, on the other hand, certain bishops began to allow believers to adopt a more comfortable life style. So the problem of the poor was attacked only at the level of its consequences and not of its causes. The poor were still dependent on the rich and, although some of the rich showed great generosity, the institutional and structural injustice which generated poverty was not dealt with at its roots.

The key figure to shape the medieval paradigm of mission thinking was Augustine of Hippo (354-430) though, strictly speaking, he preceded the Middle Ages, at least if one takes this period to have begun around 600 (Bosch 1999: 214). Augustine's circumstances and his reaction to them, influenced deeply by his personal history, were to shape both the theology and the understanding of mission of subsequent centuries. His reaction to an English monk, Pelagius, and the Donatists in North Africa essentially directed the missionary paradigm of the Middle Ages (see Frend 1985:242).

Augustine maintained that God became human in order to save human souls that are hurtling to destruction. Hence not the reconciliation of the universe but the redemption of the soul stands in the centre. The theology of Augustine could not but spawn a dualistic view of reality, which became second nature in Western Christianity - the tendency to regard salvation as a private matter and to ignore the world, though this was not the view of Augustine himself. This particular view gave rise to the tendency of seeing mission as an attempt to develop the church rather than get involved with the world (Bosch 1999:216). Augustine, however, promoted the involvement of the church with the world. In this respect he maintained that the church's involvement with social change in relation to the poor was personal charity. Augustine was the architect of the doctrine of charity; obedience to God required a genuine concern for the needs of the poor (Sider 1981:20).
The Middle Ages also saw the rise of the monastic movement which greatly contributed to the Christianisation of Europe (Tanner 2008:46). Only monasticism, says Niebuhr, saved the medieval church from acquiescence, petrification and the loss of its vision and truly revolutionary character (Quoted in Bosch 1999:230). For upward of 700 years, from the 5th century to the 12th, the monastery was not only the centre of culture and civilisation, but also of mission.

At first glance, the monastic movement appears to be a most unlikely agent for mission and transformation. The communities were certainly not founded as launching pads for mission. They were not even created out of a desire to get involved in society in their immediate environment. Rather, they regarded society as corrupt and moribund, held together only by 'the tenacity of custom'. Monasticism stood for the absolute renunciation of everything the ancient world had prized, it was an endeavour to refrain from the 'sinful world'. It was 'flight from the world, and nothing else' (Bosch 1999:231) Monasticism's one object, immediate as well as ultimate, 'was to live in purity and die in peace', and to avoid anything that could 'agitate, harass, depress, stimulate, weary, or intoxicate the soul' (Bosch 1999).

In the light of the above it may therefore sound preposterous to suggest that monasticism was both a primary agent of medieval mission and the main instrument in reforming European society. That this was indeed what happened was due, firstly, to the esteem in which the general populace held monks (Elliston 1989:7). Secondly, their exemplary lifestyle made a profound impact, particularly on the peasants. The monasteries became self-sustaining communities organised around rules for daily life, rules which pertained to work as well as prayer. This concept was revolutionary in the ancient world, where manual work was seen as fit for slaves. This concept would be emphasised again by Puritanism and have had a powerful effect on the western world.

Thirdly, their monasteries were centres not only of hard manual labour, but also of culture and education. The monks were encouraged to become scholars. Thus, for the first time the practical and theoretical were embodied in the same individuals. This combination helped create an atmosphere favourable to scientific development, including both workshops and libraries. The monasteries became centres of Christian faith, learning and technical progress as they expanded into northern Europe. According to Cannon, in the West the monasteries became 'the highway of civilisation, itself' (Cannon 1960:16). It is interesting to note how the monks related their profound spirituality to an eminently practical lifestyle. They refused to write off the world as a lost cause or to propose neat, no-loose-ends answers to the problems of life, but rather to rebuild promptly, patiently and cheerfully, 'as if it were by some law of nature that the restoration came' (Bosch 1999:233).

Henry points out that the Benedictine Rule had been 'one of the most effective linkages of justice, unity and the renewal 
the church has ever known' (1983:271-281). The Benedictine monastery indeed became a 'school for the Lord's service', and was to have a profound influence in the centuries to follow. The monastic movement, from its inception, has been concerned not only with the spiritual side of life, but also with its social and economic components. Ora et Labora was the motto of the Benedictine Order, and it also inspired many other communities. During the Middle Ages, the Church was deeply concerned about economic matters, not only on the theological level, but also on the operational one. Hospices, orphanages and philanthropic work were supported by income generated through economic activities. However, most of these were done through the monasteries. Julio De Santa Ana points out that it was the monasteries that chose to radically eradicate poverty (1979:62). The monks saw the need to be involved in the transformation of society as their gospel responsibility.

However, the concept of social or community transformation adopted by the medieval church can be classified as that of the conservative paradigm, poverty is just there: 'The poor you will always have with you' (Mk 14:7). The relationship of rich and poor is a personal one of mutual rights and obligations, which are ordained by tradition. The responsibility of the rich towards the poor is to behave with fairness, forbearance and compassion. The responsibility of the poor, as taught in the medieval church, was to accept their place in life humbly, being hardworking, law-abiding, loyal and grateful for the charity of the rich. This is, usually, reflected in relief programmes to ease immediate hardship and in welfare approaches concerned with meeting 'basic needs'. More broadly, it is seen in institutions such as the 'poor relief' at the parish level. The provision of such support is often seen as an important part of the role of the Church. While the church in the medieval period took seriously its responsibility to the poor it did not really seek to restructure society. Instead it took the poor and struggling people into the monasteries and cared for them there. This was to change with the coming of the Reformation.

\section{The Reformation}

The period of the Reformation saw the rise of mercantilism and then industrial capitalism. By 1300, before the reformation, there were many thriving cities and larger towns. The growth of towns and cities led to a growth of rural-urban specialisation. With urban workers severing all ties to the soil, the output of manufactured goods increased impressively. The expansion of trade, particularly longdistance trade in the early period, led to the establishment of commercial and industrial towns that serviced it. And the growth of these cities and towns, as well as their increased domination by merchant capitalists, led to important changes in both industry and agriculture (Hunt \& Sherman 1981:13). Each of these areas of change, particularly the latter, brought about a weakening and ultimately a complete dissolving of the traditional ties that held together the feudal economic and social structure.
New systems of commercial law developed. Unlike the system of paternalistic adjudication based on custom and tradition that prevailed in the manor, the commercial law was fixed by precise code. The worker no longer sold a finished product to the merchant. Rather, the worker sold only the worker's own labour power. This led to the workers and their families becoming dependent on the merchant-capitalists. It was inevitable that such a relationship was in due course going to lead into serious conflict. England experienced a series of such revolts in the late 14th and 15th centuries. But the revolts that occurred in Germany in the early 16th century were probably the bloodiest of all. The peasant rebellion in 1524-1525 was crushed by the imperial troops of the Holy Roman emperor, who slaughtered peasants by the tens of thousands (Hunt \& Sherman 1981:13).

The early 16th century is a watershed in European history. It marks the vague dividing line between the old, decaying feudal order and the rising capitalist system. After 1500, important social and economic changes began to occur with increasing frequency, each reinforcing the other and all together ushering in the system of capitalism. In condemning greed, acquisitive behaviour, and the desire to accumulate wealth, the medieval Christian paternalist ethic condemned what had become the capitalist order's dominant motive force (Hunt \& Sherman 1981:19). The capitalist market economy demanded self-seeking, acquisitive behaviour to function successfully. From the capitalists views of the nature of humans, and their needs to be free from the extensive economic restrictions that inhibited them in the conduct of their everyday business grew the philosophy of individualism that provided the basis of classical liberalism.

By now the church had become completely secularised. Under Henry VIII, the state in the form of God's monarchy assumed the role and function of the old universal church. As a result, the people could no longer look to the Catholic Church for relief from widespread unemployment and poverty. Destruction of the power of the church had eliminated the organised system of charity. The state attempted to assume responsibility for the general welfare of society. All through this time the Christian paternalist view that promoted the general welfare of society still prevailed.

However, with the eventual emergence of industrial capitalism this paternalist view was no longer tenable. The capitalists wanted to be free not only from economic restrictions that encumbered manufacturing and commerce but also from the moral opprobrium the Catholic Church had heaped upon their motives and activities. Unfortunately the rise of Protestantism was to provide this in-road. Protestantism not only freed them from religious condemnation but also eventually made virtues of the selfish, egoistic and acquisitive motives the medieval church had so despised. In doing so it provided the moral justification that the capitalists required for their stress on individualism, greed, self-acquisitiveness and profit making (Hunt \& Sherman 1981:31-33). 
The Reformers not only influenced their society, but they were also influenced by the ideology (economic) of their time (see Stivers 1993:33-48). Consequently, the absolute biblical concern for the poor as expressed by the early church was slowly diminishing, even though groups of Christians continued to campaign for the rights of the poor, it was small in comparison to the whole church. The church was ultimately taking sides with the rich as it provided theological justification for economic and political advancement and the creation of a 'better society'. It was not a 'better society' for the poor and marginalised. We shall examine this now.

It has often been pointed out that the Reformers were indifferent, if not hostile, to mission. Gustav Warneck, the father of missiology as a theological discipline, was one of the first Protestant scholars who promoted this view (Warneck 1906:9). 'We miss in the Reformers not only missionary action', he said, 'but even the idea of missions, in the sense in which we understand them today'. More recently, however, several scholars have argued that a judgement such as Warneck's implies summonsing the Reformers before the tribunal of the modern missionary movement and finding them guilty for not having subscribed to a definition of mission which did not exist in their own time. To argue that the Reformers had no missionary vision, these scholars contend, is to misunderstand the basic thrust of their theology and ministry (Bosch 1999:244).

Luther, in particular, is to be regarded as 'creative and original thinker'. In fact, he provided the church's missionary enterprise with clear and important guidelines and principles. The starting point of the Reformers' theology was not what people could or should do for the salvation of the world, but what God has already done in Christ. God's righteousness did not mean God's righteous punishment and wrath, but his gift of grace and mercy, which the individual may appropriate in faith (see Walker 1970:304-311). With the Reformation came a fundamental theological shift in the understanding of the church's involvement in society, especially in relation to the poor. As Lindberg points out:

Luther's theological position consists essentially of the conviction that Salvation is not the process or goal of life, but rather its presupposition ... Since righteousness before God is by faith alone and salvation is the source rather than the goal of life, it becomes difficult to rationalise the plight of the poor as a peculiar form of blessedness. There is no salvific value in being poor or in giving alms. Thus when the Reformers turned to the reform of poor relief and social policy, they had a new theological foundation for their work ... They de-ideologised the medieval approach to the poor which had obscured the problem of poverty. (Quoted in Sider 1981:20)

The new theological emphasis on individual faith contributed to the growing influence of the new individualistic philosophy. The basic tenet of Protestantism, which laid the groundwork for religious attitudes that were to sanction middle-class business practices, was the doctrine that human beings were justified by faith rather than by works. The Catholic Church had taught that faith and works, which generally meant ceremonies and rituals, justified humans (for a discussion on this see Sider 1981:20). Justification by works did not mean that an individual could save himself; it meant that he could be saved through the Church. Hence, the power of the clergy, compulsory confession, the imposition of penance on the whole population gave the priest a terrifying power. These powers ensured that the medieval doctrines of the Catholic Church were not easily abandoned and that individuals were subordinated to society. The sense of community and obligation to serve the poor were deeply entrenched and maintained.

The Protestant doctrine of justification by faith asserted that motives were more important than specific acts or rituals. Each person had to search his or her own heart to discover if acts stemmed from a pure heart and faith in God. This individualistic reliance on each person's private conscience appealed strongly to the new middle-class artisans and small merchants. Such people felt quite genuinely and strongly that their economic practices, though they might conflict with the traditional law of the old church, were not offensive to God. On the contrary: they glorified God. The new doctrines stressed the necessity of doing well at one's earthly calling as the best way to please God, and emphasised diligence and hard work. These doctrines subsequently led to the spiritualising of economic processes and the belief that 'God instituted the market and exchange' (Hunt \& Sherman 1981:13). This emphasis, however, sadly took the Christian focus away from the general concern for the community and the obligation to the poor. It gave acceptance to the liberal paradigm: poverty as backwardness. It said that those who are poor or 'backward' should not be controlled, but enabled to reach their full potential. Poverty is the result not of the natural order, but of incomplete development. As this suggests, the liberal world-view is historically intertwined with modernity.

Luther's theological position, however, was to influence his care and concern for the poor. The result was the formulation of new social policies to deal with major economic and social change. Luther and his colleague Karlstad made provision in Wittenberg for the city council to provide low-interest loans for workers; subsidies for education and training for the children of the poor; taxes to support the poor - all designed to prevent as well as alleviate poverty (Sider 1981:22). In 5 years, they changed the theory and practice of poor relief, which had been established by centuries of ecclesiastical tradition. They were convinced that fundamental human rights of equality, freedom and brotherly love had their source in the Christian faith. However, Luther also believed that this task of social change was essentially a task for the secular ruler and kingdom to carry out. This was the birth of the two 'kingdoms' theory. Luther introduced two authorities (i.e. 'kingdoms'): spiritual and civil justice and order which relates to Augustine's separation of the City of God from the world. Both are ordained by God as forces to combat the empire of Satan. Christians are subject to both authorities; firstly, however, to the spiritual authority and because they 
are subject to both authorities, Christians cannot live exclusively in either the spiritual 'kingdom' or the civil 'kingdom' (McGrath 2012:20). This theory helped to strengthen the separation of state and church.

John Calvin's theology was one which took the believer's responsibility in the world more seriously than Luther. For Calvin, the Christ who was exalted to God's right hand was pre-eminently the active Christ. In a sense, Calvin subscribed to an eschatology in the process of being fulfilled. He used the term regnum Christi [the reign of Christ] in this respect (McKim 1984:175), viewing the church as intermediary between the exalted Christ and the secular order. Such a theological point of departure could not but give rise to the idea of mission as 'extending the reign of Christ', both by the inward spiritual renewal of individuals and by transforming the face of the earth through filling it with 'the knowledge of the Lord' (McKim 1984:175). This particular view led Calvin into bringing about social transformation in Geneva. He believed that the best possible way to transform society was to make it a truly Christian community. It is interesting to note how he linked his religious views with the transformation of society. He believed that his own time was caught up in a spiritual and moral crisis whose resolution required his own ardent efforts. To set the world right was what he was most insistently 'called' to do; 'God sends prophets and teachers', he proclaimed, 'to bring the world to order' (Bouwsma 1988:192). This is what he attempted to do in Geneva.

Calvin's programme for dealing with the problems of his own age was based on his conception of God as 'legislateur et roy' [Ruler] of the universe. It was crucial for him 'that God governs us' (Bouwsma 1988:192). 'When our Lord Jesus Christ appeared', Calvin declared:

he acquired possession of the whole world; and his kingdom was extended from one end of it to another, especially with the proclamation of the Gospel ... God has consecrated the entire earth through the precious blood of his Son to the end that we may inhabit it and live under his reign. (Sermon No. 45 on Deut., 426-427)

This meant that religious reform pointed also to the reform of the secular realm. Calvin added that believers 'truly worship God by the righteousness they maintain within their society'. For those acquainted only with the characteristic theological face of Calvin, it must be noted that Calvin's theological thinking, like all great classic theologians, was deeply involved with the structures and realities of everyday life. W.F. Graham (1971) observes that:

For Calvin the world was to be taken seriously, and for him the real world involved shoemakers, printers, and clockmakers, as well as farmers, scholars, knights, and clergymen. Calvin's world-affirming theology is quite apparent. (p. 91)

It must be made clear, however, that even though Calvin argued for Christian involvement in the world he maintained a clear position about the world to come. In this sense the Christian stance which Calvin urges is a via media. Christians are to live midway between the 'brutish love of this world' (Inst. 3.9.1) characteristic of the sinful self and the final perfection and blessedness which the saints will achieve in the 'kingdom of God' (Ins. 3.9.6). What separates godly people from the worldly is 'their opposite attitudes to this present world and beyond' (Ins. 3.9.6).

With this view in mind Calvin attempted to transform the society of his day. It was an endeavour to create a better world in which everyone could live with justice, righteousness and peace. By and large, we know from Calvin's preaching that he tried to reform Geneva from the pulpit and state policies. Whereas medieval society was largely one where common men were non-participants:

Calvinism taught previously passive men [sic] the styles and methods of political activity and enabled them successfully to claim the right of participation in that on-going system of political action that is the modem state. (Graham 1971:60)

Here again is evident a responsibility for society fostered by the Calvinist insistence that the will of God must extend to the total community.

Like Luther, Calvin expressed a particular concern for the poor. He pointed out that the poor, in fact, serve a positive function in God's overall scheme of things. As his procureurs or receveurs, they serve as a type of barometer of the faith and charity of the Christian community:

God sends us the poor as his receivers. And although the alms are given to mortal creatures, yet God accepts and approves them and puts them to one's account, as if we had placed in his hands that which we give to the poor. (Sermon 95 on Deut 15: 11-15 [CO 27.338])

For this reason he severely criticised, 'the apparently liberal, who yet do not feel for the miseries of their brothers' (Commentary on 1 Jn 3:17 [CNTC 12.277]). Calvin did not oppose wealth as such; he, however, was concerned that God's gifts be used for the relief of the whole community of God's people. Indeed, if there is any central theme in Calvin's social and economic thought, it is that wealth comes from God in order to be used to aid our brethren. The solidarity of the human community is such that it is inexcusable for some to have plenty and others to be in need.

Calvin considered poverty a serious problem. He believed that it was the Christian's responsibility to address this issue. Calvin and his pastors lived in conditions close to poverty, raising funds for the needy and lobbying the state to act for the poor. He employed the traditional organic metaphor for society (as found in Ac 2:42ft), in which, as he wrote, no member has 'power for itself nor applies it to its own private use, but each pours it out to the fellow members'; what chiefly matters is 'the common advantage of the whole body' (Inst., III, vii, 5). Occasionally he identified this community with the whole human race. 'All people', he could maintain, 'are bound together as a sacred chain ... [which] ... should be embraced in one feeling of love' (Commentary Ac 13:36; Inst., II, viii, 55). 
This particular view generally yielded, for him, to a more practical view of community based on neighbourhood. 'All the blessings we enjoy', he proclaimed, 'have been entrusted to us by the Lord on this condition, that they should be dispensed for the good of our neighbors' (Inst., III,vii,5). What we see here in Calvin's teachings is that we have moral responsibility as individuals, to act with personal integrity and show love towards one another. But we also have a collective responsibility for the society in which we live. We cannot act justly as individuals, if structures within which we live are unjust. The vision of Christianity then is a corporate vision to transform the world in which we live.

In Calvin's view money and goods ought to circulate in human society to the welfare of all. Humanity in solidarity one with another would participate in contributing according to one's vocation to the good of all. He maintained that the church teaches and acts to promote equality and restore human solidarity. It helps people to put their property to use of all. Calvin saw the governing authorities as the agents of God for the welfare of the people. He thus condemned the rich and powerful who exploited their material edge to increase the poverty of the poor. He insisted on personal morality, righteousness and hard work. He seriously attacked the lazy who did not contribute towards a working society. His stress on hard labour led to a distorted view that linked hard labour with salvation. However, Calvin certainly did not intend this. He rather assumes hard work, but he wanted it clearly understood that hard labour did not give wealth. Only God provides wealth. No one will be advanced unless God advances him or her. Calvin's stress on hard labour was to be taken and used by the capitalists to justify their personal ego, greed and selfish-acquisitiveness (see, for example, Weber 1930). Preston points out, 'Calvinism did crystallise its ethic round the new commercial society, and in a more confused way Catholic moral theologians were to follow' (Preston 1979:92). Tawney rightly points out that in an age of impersonal finance, world markets and capitalist organisations, the church tried to moralise economic relations by treating every transaction as a law of personal conduct (in Preston 1979:92). This is to say that in its individualism it failed to comprehend the new structures of economic life and the power relations that went with them. Traditional Christian thought on social issues became increasingly irrelevant, and in the end capitulated uncritically to the laissez faire view of the state and the economic order. The latter, however, was not intended. This view is supported by an examination of Calvin's interest in the welfare of the poor.

Calvin's concern for the poor resulted in his attempt to transform his society, especially in Geneva. He concerned himself with the issues of commerce and economic justice (Olson 1989:12). His theology was not disembodied, divorced from the realities of life where labourers and employers are often at odds over economic matters. Calvin realised that because of the nature of humanity and the sinfulness all of our institutions, our endeavours are to some extent motivated by self-interest, pride and greed. Yet his is a 'world-affirming theology' in the sense that he sought to apply the gospel to all of life. For him, that meant seeking the guidance of scripture for the problems besetting humanity, particularly those besetting the citizens of Geneva. Thus Calvin as a theologian and pastor became involved in everyday matters as diverse as the high cost of dying, hospitals, sumptuary laws and the regulation of business and industry and the question of wages (Olson 1989:13). Calvin and Farel instituted the first free public education for both sexes. Beyond the welfare system and education the work of Calvin and the pastors reached out to suggestions for railings to protect children on stairs and balconies. Fires and chimneys were regulated and efforts were made to clean the town and for street repair. Regulation of prices for the necessities of life was an accepted principle of the early reformation in Geneva (McKim 1984:301).

At the heart of the reformation was the intent to reform, revive and renew the church. In their minds the church was not standing up to the realities of its time in confronting financial corruption, sexual immorality and political power. Reformers such as Luther, Calvin, Zwingli and others called for the 'reawakening' of the Church to address these issues. In so doing they did not hesitate to point out the inadequacies and corruption of the church which impacted on its life, work, witness and theology. Thus the 16th century Protestant Reformation was an attempt to reform and transform both church and society. The Reformation embraced a number of quite distinct, yet overlapping, areas of human activity: the reform of both the morals and structures of church and society, new approaches to political issues, shifts in economics thinking, the renewal of Christian spirituality and the reform of Christian doctrine (McGrath 2012).

The Reformers generally advocated an involvement with the world (though not all of them, for example, the Anabaptist). However, unlike the Middle Ages, they went a step further in the attempt to transform society. ${ }^{3}$ Their theology in many ways encouraged the transformation and development of community. And this they engaged as they influenced social and economic policies of the government of the day (Stivers 1993:33-48). It is thus not surprising that some 'secular interpretations' tend to discount the importance of the religious element in the Reformation. They simply state that Luther, Calvin, Knox, Zwingli and others are products of their socio-economic and political backgrounds and circumstances (Van Der Walt 1991:211). Further, the school of social history that views the religious motives behind the Reformation as marginal phenomena specific to the period has, not surprisingly, found the thesis that the Reformation failed to be very attractive (Oberman 2004:23). As Gerald Strauss argues, the 'official Christianity' throughout the centuries was able to capture only a very narrow elite layer of the population, not the 'underground' constituted by popular culture (Strauss 1978:303). It can be said of Luther and Calvin,

3. Some have said that 16 h century reforms were the beginning of a new era. Others feel they were a product of cumulative feel they were a product of cumulative changes in social welfare in the late medieval pa. sticuly to interested humanists or to better busin to the Renaissance and particularly to interested humanists or to better business practices during the Renaissance. Some also attribute the changes in social welfare to the Protestan Reformation (Olson 1989:22). 
for example, that they did have a vision of the 'common man' and wanted to remodel faith in a practical and lasting way. However, did they want or attempt to realise Reformation in the terms of transformation? Steven Ozment (1980) offers a significant affirmative comment in response to this question:

The great shortcoming of the Reformation was its naïve expectation that the majority of people were capable of radical religious enlightenment and moral transformation, whether by persuasion or by coercion. (p. 437)

There can be no doubt that other factors played a role but the religious one cannot be ignored. The Reformation movement did not only renew and change the church leaving the world uninvolved. This movement intervened dramatically in the lives of all and brought about radical changes in the social, political and economic aspects of a new developing world. It gave rise to a new epoch in the history of humankind. And all through this time there were small groups of Christians who kept to the task of transforming the lives of the poor. It is thus not surprising that one of the theological miracles of the late 20th century is the rediscovery of the biblical witness to God's particular concern for the poor and oppressed. ${ }^{4}$ This became the major focus of the ecumenical church, in particular. We shall now show this by focusing on the church in South Africa. ${ }^{5}$

\section{The church as transformation and change agency in South Africa}

The early missionaries, especially in the 19th century, are to be commended for sowing the seed from which the black churches of the 20th century grew. They did extensive evangelistic work and built churches, schools and hospitals. ${ }^{6}$ Not only were these important aspects of their ministries at that time, but were also foundations for subsequent developments. John de Gruchy (1979) points out that Black Theology has its foundations in the work of the early missionaries:

... whatever the faults of the missionaries, from a black as well as a white perspective, it is true to say that the church's struggle against racism and injustice in South Africa only really begins in earnest with their witness in the nineteenth century. (p. 13)

The church has been involved in the establishment of society, though its contributions were not at all times positive. In South Africa the Dutch Reformed Church, in particular, used its economic and political power to secure the rights of the white minority, seriously impoverishing the majority black people in South Africa, and even providing theological justification for such economic and political policies by misinterpreting Calvin's theology. This was evident in the policy of separate development which led to the rich white

4.Calvin and Luther showed a particular interest in the poor. Luther's distinction between Law and Gospel pointed out that humans are set free from sin by God's grace. This freedom enables humans to do good to fellow human beings. This encouraged the church to reform its actions towards the poor and oppressed.

5.Again, my intent in the next section is not to give a detailed account of the church in South Africa but to show the argument of this study that the church has always been involved in the transformation of society and community.

6.For a critical account of this see Pillay (2002). getting richer and the poor black getting poorer. This is a classic example of how Reformed theology was [ab]used to perpetuate racial and economic injustice. Duchrow points out that we need to today understand and judge the theological positions of the Reformation and the resultant churches on the double criteria: (1) are they life-enhancing? (2) Do they follow the Bible in socio-historic precision, which means in terms of content, and contribute to liberation for justice? (Duchrow \& Jochum-Bortfeld 2015:20). This is precisely what Allan Boesak did in his academic contributions, preaching, church leadership and in his brief stint in politics. Particularly outstanding is his theological contributions and his pioneering efforts to interpret Reformed theology in the South African and African context. Given the devastating misinterpretation of Reformed theology and tradition in the justification of apartheid, Boesak managed to recapture the true essence of what Reformed theology is all about. His books Farewell to Innocence (1976) and Black and Reformed (1984), among others, are incredible attempts to cast a new light on Reformed theology while seriously engaging the black experience and context. This is further explored in his endeavour to connect the concept and quest for an African renaissance with Christian theology and faith which he does so well in his book The Tenderness of Conscience (2005).

In essence, living under apartheid the (ecumenical) church had no real choice but to fight for the majority of people who were poor and oppressed. In living out the gospel it attempted to transform society and enhance the quality of life of the poor and oppressed. In this sense the church has a history of being a transformation and change agent in South Africa. This can be seen by some of the things we will now mention.

In 1949, the Christian Council of South Africa (CCSA) started to protest against the apartheid laws imposed by the Nationalist Government in South Africa. In October 1954 a circular was sent to heads of churches and superintendents of missions to investigate their attitude towards the Bantu Education Act. The Committee believed that the Act would violate certain principles of education. This greatly stirred the Sharpeville incident in 1960, and the subsequent banning of black organisations. The result was the Cottesloe Consultation, led mainly by dissatisfied Reformed Christians reacting to racism, in December 1960 which attempted to address 'Christian race relations and social problems in South Africa'.

Clearly, one can see from this that the CCSA was working towards the transformation of the human person and community, free from discrimination, racism, exploitation and oppression. Assisted by the World Council of Churches, a Department of Inter-Church Aid was started in 1962, to collect and distribute funds for disaster relief and community development projects. In 1968 the CCSA became known as 'The South African Council of Churches' (SACC). The SACC became more and more a place where the Churches could witness together on the problems which faced them in South Africa - above all, the social and political problems produced 
by the government's apartheid policy. They sought to address these as they witnessed to the Lordship of Jesus Christ in South Africa.

Further, the evil of apartheid was clearly exposed in two documents that attempted to express a Christian and theological understanding of South African society: The Message to the People of South Africa (1968) and The Kairos Document (1985). The message was a serious attempt to interpret what the gospel of our Lord Jesus Christ means and implies within our complex and difficult situation (Balia 1989:33). The key question concerning the message was: Who does my first loyalty go to - a human being; an ethnic group; a tradition; a political ideology or to Christ? The document called on Christians to be truthful to the gospel of Jesus Christ and to be aware of the false gospel (apartheid). The message stated that apartheid by its very nature is both divisive and antithetical of a just social order and reconciliation. Hence, it established that the struggle for justice is for the sake of overcoming the alienation of our social order and enabling reconciliation between the conflicting parties to become a reality (De Gruchy 1979:13). The most significant fact that emerges here is that the 'message' drew the church into addressing the socio-economic and political injustices of the time. This was to be further enhanced by the formulation of the Kairos Document much later.

The Kairos Document (1985) is a Christian, biblical and theological commentary on the political crisis in the country that took seriously the experiences of black people. The document spoke of the crisis in the church, which was born out of the divisions in the church. Consequently three trends developed from these divisions, that is, state, church and prophetic theology. The document challenged the state on its ideologies and condemned apartheid as a heresy. More particularly it challenged church theology in three interrelated ways (Nurnberger \& Tooke 1988:16-18). Firstly, it pointed out that church theology lacked social analysis and that the analysis of apartheid that underpins its theology is simply inadequate. Secondly, this theology lacked an adequate understanding of politics and political strategy. Changing the structures of a society is fundamentally a matter of politics. It requires a political strategy based upon a clear social or political analysis. The Church has to address itself to these strategies and to the analyses upon which they are based. It is into this political situation that the Church has to bring the gospel. Hence there is no way of bypassing politics and political strategies. Thirdly, it challenged the type of faith and spirituality that has dominated church life for centuries. Spirituality has tended to be an other-world affair that has very little, if anything at all, to do with the affairs of this world. Social and political matters were seen as worldly affairs that have nothing to do with the spiritual concerns of the church. The Kairos Document rejected this notion. It asserted that the Bible does not separate the human person from the world, in which he or she lives; it does not separate the individual from the social, or one's private life from one's public life. God redeems the whole person as part of God's whole creation. Hence a truly biblical spirituality would penetrate into every aspect of human existence and would exclude nothing from God's redemptive will. We see in this document a new theological orientation in South Africa that directed itself to a radical social involvement.

The document did not give a blueprint for an alternative political future, but challenged the church to side with God by deliberately supporting the oppressed and poor. The challenge of the Kairos Document led to the 'Concerned Evangelicals' and other people drafting documents like the 'Pentecostal Witness in South Africa' (1986) and 'A Relevant Pentecostal Witness' in 1988 (Hofmeyer \& Pillay 1994:288).

The ecumenical movement in South Africa identified itself with the poor as it joined forces with the exploited working class. Embracing liberation theology, it insisted that God is on the side of the poor and it therefore joined with the poor to fight for justice and human rights. In seeking the liberation of the oppressed it radically opposed the structures that dehumanised the masses. It encouraged the participation of the poor in the processes of enabling them to become more human and took up the struggle for justice.

For Allan Boesak, who comes from the Reformed tradition, the issue of justice is crucial; it is part and parcel to the Christian Gospel. In fact, it is the declaration of the Lordship of Jesus Christ. Whenever Christians speak out and act against injustice, inequality and the dehumanisation of the human being, they serve as the ambassadors and servants of Christ. Boesak singles out the Belhar Confession (1986) in this respect where it states:

in a world filled with injustice and enmity God in a special way is the God of the destitute, the poor and the wronged ... that the church as God's possession is called to stand where God stands, namely against injustice and with the wronged. (p. 3)

Boesak points out that this Confession helps us to, firstly, stand up (and be counted) for the poor and the destitute, and secondly, to stand where God stands. Not just in front of, in protection, but alongside, in solidarity of struggle. Not in mere sympathy but in identification with. The church must do that not because it is obsessed with the poor, but as the possession of God, in Whom its grounds of being, its identity is found (Boesak 2005:200).

The SACC raised consciousness of the oppressed in South Africa both internally and internationally. It actively resisted the apartheid laws that were imposed on the majority people in South Africa by calling for disinvestments and international sanctions on South Africa. The World Alliance of Reformed Churches played a vital role in this regard by suspending the membership of the Dutch Reformed Church and supporting the call for disinvestments in South Africa. The SACC played a very vital role in the demise of apartheid, and it continued to play a role in the reconstruction and transformation of South Africa since then. It is not possible to cover these details in this study but the point I wish to make here is that 
the (ecumenical) church in South Africa has always served in the role of bringing about transformation and change.

The beginning of the 20th century saw the rise and development of the African Independent Churches (AICs; see Hofmeyer \& Pillay 1994:167-193). Originally the whole phenomenon of African Independent Christianity was interpreted as a protest against the Westernisation of the Christian mission in South Africa. More recent research has shown that the complex phenomenon of the AICs cannot be attributed simplistically to a single protest factor (Saayman 1990:32). It can be established that the rise of the AICs was an attempt to preserve, develop and transform the African community and way of life. The AICs, especially the Zionists, attempted to develop and give expression to the African way of life. This quest was further realised in the rise of African Christian Theology. African Christian Theology is a deliberate attempt to strip Christianity of non-essential additions. African Christian Theology is a decision by Africans to worship God as Africans and to look at and interpret the Bible from an African perspective. It attempts to build on the existing African religious tradition (Pobee 1979:15). It tries to tap the resources of the entire African community in arts, literature, sculpture and all human and academic disciplines. The concern of African Theology is to attempt to use African concepts and African ethos as vehicles for the communication of the Gospel in an African context. This, undoubtedly, is a further indication of the role the church played and continues to play in the transformation of society and community.

This ecumenical impact on missional thinking can be seen in South Africa today. Many are of the opinion that ecumenism in South Africa is dying, and this view is largely associated with the struggles of the SACC to survive, mainly financially. In my opinion, ecumenism is not dying; instead, it is morphing into something new. This new development is not driven by ecclesiology, doctrine, tradition and denominationalism but by a missional focus. The essential question is: How can we work/partner together in God's mission in transforming society and country? How can we exercise a prophetic voice together? How can we journey with the poor? The evangelical churches, in particular, are at the forefront seeking to influence government and business with the gospel. Sometimes one wonders whether their goal in mission is Christianisation or transformation. Whatever the intentions, one thing is sure that we are experiencing what I call a missional revolution with the intention of inspiring, motivating, equipping and nurturing Christian disciples. We are realising that the goal is not to get people to church but to get the church into the world to transform the world with the justice and peace of God so that all may experience the 'fullness of life' on the earth. In this endeavour the church has to work with government, business and labour and other religious bodies to create a better life for all people.

In a recent meeting The World Communion of Reformed Churches had with Pope Francis (10th June 2016) in the
Vatican to discuss Reformed-Catholic relationships, he pointed out that 'our faith in Jesus impels us to live charity through concrete gestures capable of affecting our way of life, our relationships and the world around us' (p. 2). In this context he heightened the role of the church as an 'Agent for Justice'. He went further to state: 'There is urgent need for an ecumenism that, along with theological dialogue aimed at settling traditional doctrinal disagreements between Christians, can promote a shared mission of evangelisation and service'. It is the latter that is of significant interest today. The world is not so much interested in what we believe today but in what the church is doing to transform society and the world so that justice and peace may prevail.

\section{Conclusion}

In this article, we have shown that the Christian church has always been involved in the transformation of society, especially as it took sides with the poor and oppressed. At times it seemed to have lost this focus, but somehow, throughout the ages, it has managed to sustain this mission responsibility. Today, more than ever, given the increasing poverty, violence and injustices in the world, the Christian church is called upon to embrace, engage and continue with its task of being an agent for transformation and change. It has to fulfil the gospel imperative of making the world a better place for all to live with justice, peace and harmony.

\section{Acknowledgements Competing interests}

The author declares that he has no financial or personal relationships which may have inappropriately influenced him in writing this article.

\section{References}

Balia, D.M., 1989, Christian resistance to apartheid, Skotaville, Braamfontein. Batey, R., 1972, Jesus and the poor, Harper \& Row, New York.

Belhar Confession, 1986, Belhar Confession 1986 English translation, viewed 28 September 2016, from http://images.rca.org/docs/aboutus/BelharConfession. pdf[2016]

Boesak, A., 1976, Farewell to innocence. A social-ethical study of black theology and power, Ravan, Sandton, South Africa.

Boesak, A., 1984, Black and Reformed apartheid, liberation and the Calvinist tradition, Skotaville Publishers, Johannesburg.

Boesak, A., 2005, The tenderness of conscience - African Renaissance and the spirituality of politics, Sun Press, Stellenbosch.

Bosch, D.J., 1999, Transforming mission: Paradigm shifts in theology of missions, Orbis Books, New York.

Bouwsma, W.J., 1988, John Calvin: A sixteenth century portrait, Harper \& Row, New York.

Cannon, W., 1960, History of Christianity in the middle ages, Abingdon, Nashville, TN.

Cochrane, C.N., 1974, Christianity and classical culture: A study of thought and action from Augustus to Augustine, Oxford University Press, New York.

De Gruchy, J.W., 1979, The church struggle in South Africa, David Philip, Cape Town.

De Santa Ana, J., 1979, Good news to the poor: The challenge of the poor in the history of the church, WCC, Geneva.

Duchrow, U. \& Jochum-Bortfeld, C., 2015, Liberation toward justice, LIT VERLAG. Dr. W. Hopf, Berlin.

Elliston, E.J., 1989, Christian relief and development: Developing workers for effective ministry, Word Publishing, Dallas, TX.

Frend, W.H.C., 1985, The Donatist church: A movement of protest in Roman North Africa, Clarendon, Oxford. 
Graham, W.F., 1971, The constructive revolutionary: John Calvin and his socioeconomic impact, John Knox Press, Geneva.

Henry, P., 1983, 'Monastic mission: The monastic tradition as source for unity and renewal today', The Ecumenical Review 39, 271-281. https://doi.org/10.1111/j. 1758-6623.1987.tb01417.x

Hofmeyer, J.W. \& Pillay, G.J. (eds.), 1994, A history of Christianity in South Africa vol. 1, HAUM Tertiary, Pretoria.

Hunt, E.K. \& Sherman, H.J., 1981, Economics: An introduction to traditional and radical views, Harper \& Row, New York.

Kairos Document, 1985, 'The Kairos document', in W.H. Logan (ed.), The Kairos covenant, pp. 2-43, Friendship Press, New York.

McGrath, A.E., 2012, Reformation thought an introduction, Wiley-Blackwell, Oxford.

McKim, D.K., 1984, Readings in Calvin's theology, Baker Book House, Grand Rapids, MI.

McNeal, R., 2009, Missional Renaissance: Changing the scorecard for the church, Jossey-Bass, San Franciso, CA.

Nurnberger, K. \& Tooke, J. (eds.)., 1988, The cost of reconciliation in South Africa, NIR reader no. 1, Methodist Publishing House, Cape Town.

Oberman, H.A., 2004, The reformation roots and ramification, T\&T Clark International, London.

Olson, J.E., 1989, Calvin and social welfare, Associated University Presses, London.

Ozment, S., 1980, The age of Reform 1250-1550. An intellectual and religious history of late medieval and Reformation Europe, Yale University Press, New Haven, CT.

Perkins, J., 2005, 'Fictional narratives and social critique', in V. Burrus (ed.), Late ancient Christianity, a people's history of Christianity, pp. 42-54, Fortress Press, Minneapolis, MN.

Pillay, J., 2002, 'The church and development: Towards a theology of development', PhD thesis, University of Cape Town, Cape Town.
Pobee, J.S., 1979, Towards an African theology, Abingdon, Nashville, TN.

Preston, R.H., 1979, Religion and the persistence of capitalism, SCM Press, London.

Saayman, W., 1990, 'Christian missions in South Africa: Achievements, failures and the future', in M. Prozesky (ed.), Christianity in South Africa, pp. 18-24, Southern Book Pub, South Africa.

Scott, W., 1987, 'Mercy and social transformation', in V. Samuel \& C. Sugden (eds.), The Church in response to human need, p. 208ff., Eerdmans, MI.

Sider, R., 1981, Evangelicals and development: Towards a theology of social change, contemporary issues in social ethics, vol. 2, The Paternoster Press, Fitzroy Falls, NSW, Australia.

Stanmaugh, J. \& Balch, D., 1986, The social world of the first Christians, Anchor Press, Great Britain.

Stivers, R.L., 1993, Reformed faith and economics, University Press of America, Lanham, MD.

Strauss, G., 1978, Luther's house of learning. Indoctrination of the young in the German Reformation, Sage, Baltimore, MD.

Tanner, N., 2008, The church in the later middle ages, I.B. Tauris, New York.

Van Der Walt, B.J., 1991, Anatomy of Reformation, Potchefstroom University for CHE, Potchefstroom.

Von Harnack, A., 1967, The mission and expansion of Christianity in the first three centuries, Harper, New York.

Walker, W., 1970, A history of the Christian Church, T. \& T. Clark Ltd, Edinburgh.

Warneck, G., 1906, Outline of a history of protestant missions, SCM Press, London.

Weber, M., 1930, The protestant ethic and the spirit of capitalism 9195, E. T. Allen \& Unwin and Scribner's, Australia.

Winter, B., 1994, Seek the welfare of the city: Christians as benefactors and citizens. First-century Christians in the Graeco-Roman World, Eerdmans, Grand Rapids, MI. 